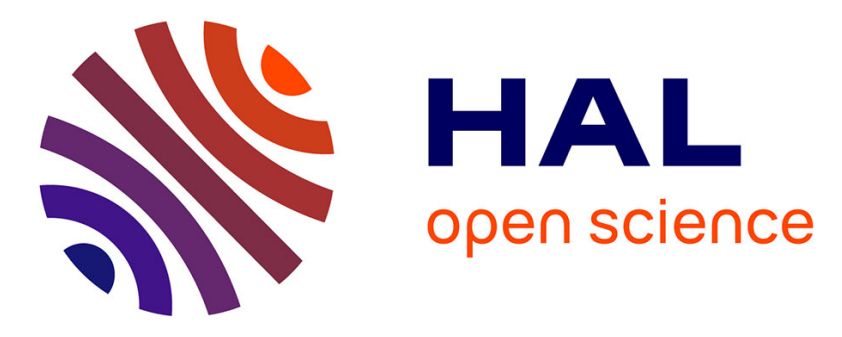

\title{
The dinoflagellate Alexandrium minutum affects development of the oyster Crassostrea gigas, through parental or direct exposure
}

Justine Castrec, Helene Hegaret, Marianne Alunno-Bruscia, Maïlys Picard, Philippe Soudant, Bruno Petton, Myrina Boulais, Marc Suquet, Isabelle Queau, Dominique Ratiskol, et al.

\section{To cite this version:}

Justine Castrec, Helene Hegaret, Marianne Alunno-Bruscia, Maïlys Picard, Philippe Soudant, et al.. The dinoflagellate Alexandrium minutum affects development of the oyster Crassostrea gigas, through parental or direct exposure. Environmental Pollution, 2019, 246, pp.827-836. 10.1016/j.envpol.2018.11.084 . hal-02324570

\section{HAL Id: hal-02324570 \\ https://hal.science/hal-02324570}

Submitted on 3 Jun 2020

HAL is a multi-disciplinary open access archive for the deposit and dissemination of scientific research documents, whether they are published or not. The documents may come from teaching and research institutions in France or abroad, or from public or private research centers.
L'archive ouverte pluridisciplinaire HAL, est destinée au dépôt et à la diffusion de documents scientifiques de niveau recherche, publiés ou non, émanant des établissements d'enseignement et de recherche français ou étrangers, des laboratoires publics ou privés. 


\title{
The dinoflagellate Alexandrium minutum affects development of the oyster Crassostrea gigas, through parental or direct exposure
}

\author{
Castrec Justine ${ }^{1}$, Hégaret Helene ${ }^{4}$, Alunno-Bruscia Marianne ${ }^{2}$, Picard Maïlys ${ }^{1}$, Soudant Philippe ${ }^{1}$, \\ Petton Bruno ${ }^{2}$, Boulais Myrina ${ }^{1,3}$, Suquet Marc ${ }^{2}$, Quéau Isabelle ${ }^{2}$, Ratiskol Dominique ${ }^{2}$, \\ Foulon Valentin ${ }^{1}$, Le Goïc Nelly ${ }^{1}$, Fabioux Caroline ${ }^{1,{ }^{*}}$
}

${ }^{1}$ LEMAR UMR 6539 CNRS/UBO/IRD/Ifremer, IUEM, rue Dumont d'Urville, 29280, Plouzané, France

2 Ifremer, LEMAR UMR 6539 CNRS/UBO/IRD/Ifremer, Centre de Bretagne, CS 10070, 29280,

Plouzané, France

${ }^{3}$ University of North Carolina Wilmington, Center for Marine Science, 5600 Marvin K. Moss Lane, Wilmington, NC, 28409, USA

* Corresponding author : Caroline Fabioux, email address : caroline.fabioux@univ-brest.fr

\begin{abstract}
:
Harmful algal blooms are a threat to aquatic organisms and coastal ecosystems. Among harmful species, the widespread distributed genus Alexandrium is of global importance. This genus is wellknown for the synthesis of paralytic shellfish toxins which are toxic for humans through the consumption of contaminated shellfish. While the effects of Alexandrium species upon the physiology of bivalves are now well documented, consequences on reproduction remain poorly studied. In France, Alexandrium minutum blooms have been recurrent for the last decades, generally appearing during the reproduction season of most bivalves including the oyster Crassostrea gigas. These blooms could not only affect gametogenesis but also spawning, larval development or juvenile recruitment. This study assesses the effect of toxic $A$. minutum blooms on $C$. gigas reproduction. Adult oysters were experimentally exposed to $A$. minutum, at environmentally realistic concentrations $\left(10^{2}\right.$ to $10^{3}$ cells $\left.\mathrm{mL}^{-1}\right)$ for two months during their gametogenesis and a control group, not exposed to $A$. minutum was fed with a non-toxic dinoflagellate. To determine both consequences to next generation and direct effects of $A$. minutum exposure on larvae, the embryo-larval development of subsequent offspring was conducted with and without $A$. minutum exposure at $10^{2}$ cells $\mathrm{mL}^{-1}$. Effects at each stage of the reproduction were investigated on ecophysiological parameters, cellular responses, and offspring development. Broodstock exposed to $A$. minutum produced spermatozoa with decreased motility and larvae of smaller size which showed higher mortalities during settlement. Embryo-larval exposure to $A$. minutum significantly reduced growth and settlement of larvae compared to non-exposed offspring. This detrimental consequence on larval growth was stronger in larvae derived from control parents compared to offspring from exposed parents. This study provides evidence that $A$. minutum blooms, whether they occur during gametogenesis, spawning or larval development, can either affect gamete quality and/or larval development of $C$. gigas, thus potentially impacting oyster recruitment.
\end{abstract}




\section{Graphical abstract}

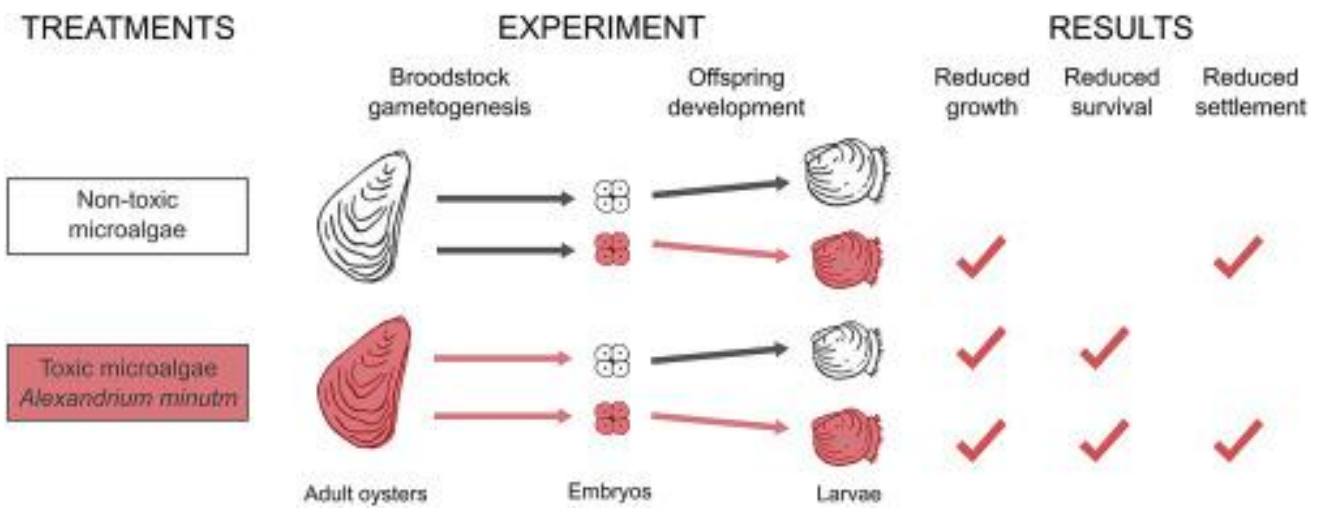

\section{Highlights}

- Two-month exposure of adult oysters to Alexandrium minutum decreased sperm motility. Oocytes and spermatozoa of exposed oysters contained paralytic shellfish toxins. Larvae derived from these gametes showed reduced growth and survival. - Exposure of oyster larvae to A. minutum altered larval growth and settlement. Adult exposure influenced offspring response to $A$. minutum exposure.

Keywords : Harmful algal bloom (HAB), Paralytic shellfish toxin (PST), Crassostrea gigas, Gametes, Larvae 
45 Harmful algal blooms (HABs) have increasingly disrupted coastal ecosystems for the last

46 few decades (Kudela et al., 2015). Among toxic species, blooms of microalgae producing

47 paralytic shellfish toxins (PST) represent an important threat for marine ecosystems, human

48 health and the economy in coastal areas. Blooms of Alexandrium affect marine ecosystems by

49 disrupting community and food web structures (Hallegraeff, 2010), and causing death of

50 seabirds and mammals (Hattenrath-Lehmann et al., 2017). The resulting PST can affect

51 humans via shellfish poisoning events (Anderson et al., 2012a), as filter-feeding bivalves

52 accumulate PST in their flesh by feeding on PST-producing microalgae (Bricelj and 
Shumway, 1998). Prohibition of shellfish harvesting, impairment of tourism and recreational activities are direct socio-economic consequences of PST-producing microalgae blooms in coastal regions (Anderson et al., 2012b). Detrimental effects of those phenomena are expected to intensify as the geographical distribution of HABs and the use of coastal waters for aquaculture are increasing worldwide (Lassus et al., 2016).

In marine ecosystems, outbreaks of Paralytic Shellfish Poisonings (PSPs) are mainly caused by the globally distributed dinoflagellate genus Alexandrium (Rossini, 2014). Blooms of Alexandrium spp. affect the physiology of bivalves including exploited species such as Mytilus edulis, Pecten maximus, Venerupis philippinarum, and Crassostrea gigas (Borcier et al., 2017; Bricelj et al., 1993; Haberkorn et al., 2010a; Lassudrie et al., 2014). Alexandrium minutum modifies valve behavior, disrupts biological rhythms, affects defense responses and digestion of $C$. gigas (Haberkorn et al., 2010b, 2011; Mat et al., 2013; Mello et al., 2013; Payton et al., 2017; Tran et al., 2010).

In France, A. minutum blooms usually occur from April to November and can reach high concentrations (> $10^{7}$ cells L ${ }^{-1}$ ) (Guallar et al., 2017, Chapelle et al., 2015). In French coastal waters, A. minutum blooms may last several months (Guallar et al., 2017) and are often concomitant with breeding period of bivalves, including the oyster $C$. gigas (Pouvreau et al., 2016; Suquet et al., 2016; Ubertini et al., 2017). Marine bivalves are ecosystem engineers and a key resource in coastal areas (Ekstrom et al., 2015). In France, 64,200 tons of Pacific oysters were produced in 2016, representing a value of 360,400 USD (FAO, 2018). In France, the natural recruitment of oyster spat constitutes a large part of cultivated stocks and repeated recruitment failures could have negative impacts on local oyster aquaculture. Given the economic importance of oysters, an understanding of the effects of Alexandrium blooms on the reproduction of $C$. gigas is critically important. Adult Pacific oysters which reproduce during the summer are frequently exposed to the harmful algae during gametogenesis. 
Gametes, embryos and larvae, the free-living stages of oysters, also directly experience the toxicity of Alexandrium with potential consequences on recruitment.

Short-term exposure of mature Pacific oysters to Alexandrium spp. affected spermatozoa quality, and in vitro exposure of oocytes to A. minutum increased reactive oxygen species production in oocytes (Haberkorn et al., 2010b; Le Goïc et al., 2013). Knowledge regarding potential effects of adult oyster exposure to ecological concentrations of HAB species on the next generation remains scarce (Rolton et al., 2018, 2016; Vasconcelos et al., 2010). Adult eastern oysters Crassostrea virginica exposed to a natural bloom of the brevetoxin producer, Karenia brevis, produced smaller larvae with higher mortality than non-exposed oysters (Rolton et al., 2016). Northern quahogs Mercenaria mercenaria exposed to K. brevis showed reduced gonadal allocation and fertilization success, and the early development of the subsequent offspring was also affected (Rolton et al., 2018). Concerning direct exposure of larvae, acute short-term exposures of Alexandrium spp. negatively affected survival, growth, activity, and settlement of bivalve larvae, including C. gigas, Pinctada fucata martensii, Mercenaria mercenaria, Chlamys farreri, and Argopecten irradians concentricus (Basti et al., 2015; Matsuyama et al., 2001; Mu and Li, 2013; Tang and Gobler, 2012; Yan et al., 2003, 2001). However, the effects of $A$. minutum blooms on oyster larvae remain unknown.

The present study investigated the effects of a 3-month exposure to toxic A. minutum at concentrations similar to natural bloom events on the gametogenesis of adult $C$. gigas and on their offspring. We assessed the weight (total, shell, and flesh), feeding, sex and gametogenesis stage of adult oysters, the quality and cellular, molecular and biochemical characteristics of gametes, and the growth, survival and settlement of larvae. The hypotheses tested were: (1) Gamete quality will be negatively affected by a long-term exposure to $A$. minutum, (2) Parental exposure may adversely affect subsequently produced offspring, and (3) Direct exposure of larvae to A. minutum will alter larval development. 


\section{Materials and methods}

104

105

106

107

108

109

110

111

112

113

114

115

116

117

118

119

120

121

122

123

124

125

126

127

\subsection{Biological materials}

Oysters. Adult oysters Crassostrea gigas (Magallana gen. nov.; Salvi and Mariottini, 2017) were produced and cultured in controlled conditions according to a standardized protocol (Petton et al., 2015), in Ifremer experimental facilities (Argenton and Bouin, France). Oysters were never exposed to any harmful algal bloom. Histological inspection at the start of the experiment in April 2016 showed that oysters (12 months old, mean total weight $18.0 \pm$ $0.4 \mathrm{~g}$ ) were in early gametogenesis (stage 1), according to Steele and Mulcahy (1999).

Algal cultures. Tisochrysis lutea (formerly Isochrysis sp., T. iso strain, CCAP 927/14) and Chaetoceros sp. (formerly Chaetoceros neogracile, strain CCAP 1010-3) were used as nontoxic food for oysters. They were cultured with continuous light $\left(200 \mu \mathrm{mol}\right.$ photons $\left.\mathrm{m}^{-2} \mathrm{~s}^{-1}\right)$ in separated 300-L cylinders enriched with Conway medium (Walne, 1970), and with silicium for Chaetoceros sp. The dinoflagellates Alexandrium minutum (Halim, AM89BM strain) and Heterocapsa triquetra (Ehrenberg, 1840; HT99PZ strain) were grown in filtered seawater (0.2 $\mu \mathrm{m})$ supplemented with L1 medium (Guillard and Hargraves, 1993) and kept in exponential growth phase. Cultures were maintained at $17 \pm 1{ }^{\circ} \mathrm{C}$. This $A$. minutum strain produced a quantity of Paralytic Shellfish Toxins (PST) equivalent to $1.3 \pm 0.1 \mathrm{pg}$ eq. STX per cell in the exponential growth phase (Haberkorn et al., 2010 a, b). This strain also produces bioactive extracellular compounds (BECs), which have allelopathic and cytotoxic activities (Borcier et al., 2017; Castrec et al., 2018; Lelong et al., 2011). The non-toxic H. triquetra was chosen as a control because of its similarity to A. minutum in terms of size and shape (Tran et al., 2015).

\subsection{Experimental exposure of adult oysters to A. minutum}

The flow chart of experimental procedure is presented in Fig. 1. After acclimation, the oysters were placed in six experimental 50-L tanks (46 oysters per tank) supplied with filtered running seawater $\left(1-\mu \mathrm{m}\right.$ filtered and UV-treated (FSW); $17.0 \pm 0.1{ }^{\circ} \mathrm{C}, \mathrm{pH} 8.3 \pm 0.1$, and 35.1 
$128 \pm 0.1 \mathrm{PSU} ; 12.5 \mathrm{~L} \mathrm{~h}^{-1}$ ), and fed continuously on an algal mixture (1:1 equivalent volume) of $T$.

129 lutea and Chaetoceros sp. (Tiso/Chaeto) at a daily ratio equal to $6 \%$ dry mass algae/dry mass

130 oyster (Petton et al., 2015). The toxic A. minutum was continuously added to Tiso/Chaeto in 3

131 replicate tanks (exposed treatment) at a concentration of $10^{2}$ cells $\mathrm{mL}^{-1}$, except during the

132 seventh week of the experiment where the concentration was gradually increased to $10^{3}$ cells

$133 \mathrm{~mL}^{-1}$ for 4 days, mimicking an A. minutum bloom event (Chapelle et al., 2015). The 3 other

134 tanks (control treatment) were exposed to the same concentrations of the non-toxic

135 dinoflagellate $H$. triquetra. Algal concentrations and exposure time correspond to

136 environmentally realistic conditions (Chapelle et al., 2015). To prevent algal sinking, the

137 water inflow was pressurized to create recirculating flow in the tank and air bubbling was

138 used. The oysters were conditioned for 8 weeks to reach ripeness.

\subsection{Algal consumption of adult oysters}

140 For each algal treatment, a fourth tank was deployed without oysters to evaluate algal

141 sinking. Once a day, inflow and outflow seawater was sampled from each tank (20 mL).

142 Phytoplankton counts were made using an electronic particle counter (Multisizer 3 equipped

143 with a $100-\mu \mathrm{m}$ aperture tube) to provide 56 days of continuous data. Algal sinking (S) was

144 evaluated in percentage of microalgae retained in the tank without oysters: $S=\left[\left(V_{0}-V_{i}\right) / V_{i}\right]$

$145 \times 100 ; V_{i}$ being the number of algae at the inlet of the control tank, and $V_{o}$ the number of

146 algae at the outlet. Algal sinking was low $(<4 \%)$ and similar in the two treatments. Total

147 algal consumption, i.e. dinoflagellate and Tiso/Chaeto, was expressed in algal cell volume per

148 oyster per hour $\left(\mu \mathrm{m}^{3}\right.$ oyster $\left.^{-1} \mathrm{~h}^{-1}\right)$, as in Sussarellu et al. (2016).

$149 \quad 1.4 \quad$ Sampling

150 At 2, 4, 6, and 8 weeks after the beginning of exposure (corresponding to T2, T4, T6 and

151 T8, respectively), five animals per tank were sampled for flesh mass, and a transversal section

152 of the gonadic area for histological examination (Fig. 1). The remainder of the digestive gland 
153

154

155

156

157

158

159

160

161

162

163

164

165

166

167

168

169

170

171

172

173

174

175

176

177

was flash frozen in liquid nitrogen and stored at $-20{ }^{\circ} \mathrm{C}$ for subsequent PST quantification. At the beginning (T0) and at the end (T8) of the experiment, 15 oysters per algal treatment were sampled to measure biometric parameters (total wet mass (TWM), wet shell mass (WSM), and dry flesh mass (DFM)). Condition index was calculated as: DFM $\times 100 /$ (TWM - WSM). Six control and 6 exposed oysters of each sex were collected after 7 weeks of broodstock conditioning (T7) for gamete quality measurements (see section 1.6).

Gametes were collected at T8 in the remaining control and exposed animals (45 oysters per treatment, 15 oysters per tank) by stripping the gonad, and pooling gametes of oysters from the same tank, for each sex. Oocytes were suspended in FSW, filtered in a $100-\mu \mathrm{m}$ sieve, and oocyte concentrations were determined by flow cytometry (FCM) according to Le Goïc et al. (2014). Oocytes were transferred in $2 \mathrm{~mL}$ tubes for PST quantification and biochemical composition measurements $\left(2 \times 10^{6}\right.$ oocytes for each analysis, stored at $\left.-20{ }^{\circ} \mathrm{C}\right)$, and for RNA analyses $\left(4 \times 10^{6}\right.$ oocytes, stored in liquid nitrogen $)$. Sperm samples for PST content and biochemical composition were obtained by direct pipetting the incised male gonad. For larval rearing, gametes were pooled for each treatment and each sex (Fig. 1).

\subsection{Histology}

A 3-mm cross section of the visceral mass was excised in front of the pericardial region and immediately fixed in modified Davidson's solution (Latendresse et al., 2002) for $24 \mathrm{~h}$ at $4{ }^{\circ} \mathrm{C}$. Tissues were processed, stained with Harris' hematoxylin-eosin, and observed as described by Hermabessiere et al. (2016). Tissue sections were examined under a light microscope (Leica DMIRB) equipped with a digital camera (Imaging RETIGA 2000R) to determine the sex and gametogenesis stage of each oyster according to the reproductive scale reported by Steele and Mulcahy (1999). In addition, measurement of reproductive effort was determined by image software $\left(\right.$ Adobe $^{\circledR}$ Photoshop $^{\circledR}$ ): gonadal occupation index is the percentage of whole gonadal area in relation to the total transverse section area (Fabioux et al., 2005). 
178

179

180

181

182

183

184

185

186

\subsection{Gamete cellular analyses}

Gamete collection. Oocytes and spermatozoa were collected at T7 for each oyster by stripping entirely the gonad, according to Boulais et al. (2017) for spermatozoa and Le Goïc et al. (2014) for oocytes. Spermatozoa were collected in $10 \mathrm{~mL}$ of FSW at $19{ }^{\circ} \mathrm{C}$ and sieved through $60 \mu \mathrm{m}$ mesh. Oocytes were suspended in FSW, sieved through $100 \mu \mathrm{m}$ to remove pieces of gonad tissue and concentrated on a $20-\mu \mathrm{m}$ sieve. Oocyte and spermatozoa concentrations were determined by FCM according to Le Goïc et al. $(2013,2014)$ and adjusted to $5 \times 10^{4}$ oocytes $\mathrm{mL}^{-1}$ and $1 \times 10^{7}$ spermatozoa $\mathrm{mL}^{-1}$, for $\mathrm{FCM}$ and cellular analyses.

Cellular parameters by flow cytometry. FCM measurements were performed using an EasyCyte Plus cytometer (Guava Millipore) equipped with standard optics and a $488 \mathrm{~nm}$ argon laser. Analyses of gamete relative size and complexity, viability, mitochondrial membrane potential (MMP), and reactive oxygen species (ROS) production were performed according to Le Goïc et al. $(2013,2014)$ for spermatozoa and oocytes.

Oocyte morphological measurements. Oocyte circularity (ranging from 0 to 1 , where a value of 1 indicates a perfect circle) and Feret's diameter (Ferreira and Rasband, 2012) were measured under microscope, using ImageJ software $(n=30$ oocytes for each female) according to Boulais et al. (2015a).

Characterization of spermatozoa movement. Spermatozoa movement was triggered using a two-step dilution in an activating solution (FSW, $5 \mathrm{~g} \mathrm{~L}^{-1}$ bovine serum albumin, Tris $20 \mathrm{mM}$, $\mathrm{pH}$ 8.1, dilution rate 1:30) and analyzed under microscope using a CASA plug-in for ImageJ software. The percentage of motile spermatozoa and their velocity (VAP: Velocity of the Average Path) were assessed on a minimum of 30 spermatozoa for each male, according to Boulais et al. (2015b). 
Quantification of ATP content in spermatozoa. Intracellular ATP content of spermatozoa

was estimated in triplicates using $5 \times 10^{6}$ spermatozoa for each male as described in Boulais et al. (2015b), by bioluminescence (kit ATPlite, Perkin Elmer) using a plate reader (EnSpire ${ }^{\text {TM }} 2300$ Multilabel Reader, PerkinElmer).

\subsection{Quantification of total RNA in oocytes}

Total RNA was isolated using Tri-reagent (Sigma), treated with rDNase (MachereyNagel), purified using affinity chromatography (Nucleospin RNA kit, Macherey-Nagel) according to the manufacturer's instructions, and assayed for concentration using a ND-1000 spectrophotometer (Nanodrop Technologies).

\subsection{Protein, lipid, and carbohydrate compositions of gametes}

Total lipids and carbohydrates were analyzed as described by Bligh and Dyer (1959), and Dubois et al. (1956), respectively. Total protein content was assayed as described by Da Costa et al. (2016). Dry weights were determined with a $400 \mu \mathrm{L}$ aliquot of the first fraction distributed in pre-weighed capsules and dried at $80{ }^{\circ} \mathrm{C}$ for $48 \mathrm{~h}$. Content of each constituent was expressed as: biochemical content of each constituent in $\mathrm{mg} \times 100 /$ dry mass of gonad in mg.

\subsection{Toxin quantification}

PST extraction was performed individually following manufacturer instructions: digestive gland tissue was homogenized in $\mathrm{HCl} 0.1 \mathrm{M}(1: 1, \mathrm{w}: \mathrm{v})$ using a Precellys ${ }^{\circledR} 24$ beads-grinder, then boiled for $5 \mathrm{~min}$. For the sampling times T2, T4, and T8, individual homogenates were pooled for each tank ( $n=3$ pools of 5 oysters for each sampling time). The PST digestive gland content was analyzed individually just before $(\mathrm{T} 6, \mathrm{n}=15)$ and after $(\mathrm{T} 7, \mathrm{n}=12)$ the high dinoflagellate bloom simulated in this experiment. Toxin quantification was performed by spectrophotometry using the Abraxis ELISA PSP kit (Novakits, France; see methods in 
Lassudrie et al. (2015)). Toxin load was expressed in $\mu \mathrm{g}$ STX $100 \mathrm{~g}^{-1}$ of wet digestive gland weight (DG) or gonad weight.

\subsection{Larval rearing}

To test the influence of parental exposure on offspring, fertilization was performed for each treatment; a pool of $15 \times 10^{6}$ oocytes (from 33 control females or 29 exposed females) were fertilized separately in a beaker using a pool of sperm (from 12 control males or 16 exposed males) using a non-limiting sperm to oocyte ratio (100:1) (Fig. 1). Embryos were transferred 1.5 hours post-fertilization (hpf) in 150-L tanks in UV-treated FSW at a concentration of 50 embryos $\mathrm{mL}^{-1}$ and maintained $48 \mathrm{~h}$ at $21^{\circ} \mathrm{C}$. D-larvae were then transferred to 5-L cylindrical triplicate tanks at the density of 50 larvae $\mathrm{mL}^{-1}$, and maintained in a flow-through rearing system $\left(100 \%\right.$ seawater renewal $\left.\mathrm{h}^{-1}, 21^{\circ} \mathrm{C}, 35 \mathrm{PSU}\right)$ (Fig. 1). The larvae were fed continuously with Tiso/Chaeto as described by Asmani et al. (2016).

To test for influence of offspring exposure, fertilization and larval rearing were performed for each algal treatment as described above, but the subsequent offspring were continuously exposed to A. minutum $\left(10^{2}\right.$ cells $\left.\mathrm{mL}^{-1}\right)$, from 4-cell embryos $(2.5 \mathrm{hpf})$ to veliger larvae (22 days post-fertilization, dpf) (Fig. 1).

Larvae were sampled every $2-3$ days and fixed in a $0.1 \%$ formaldehyde-seawater solution until image analysis for size monitoring. Larval size was assessed by measuring shell length using image analysis on at least 30 larvae per tank per day of sampling (WinImager 2.0 and ImageJ software for image capture and analysis, respectively).

A small complementary experiment was carried out on oyster larvae raised on the same conditions as the control larvae to test the capacity of larvae to ingest A. minutum cells. Umbonate larvae (mean shell length $150 \pm 22 \mu \mathrm{m}$ ) and eyed larvae (mean shell length $304 \pm$ $15 \mu \mathrm{m}$ ) were exposed to A. minutum (AM89BM strain) and the presence of $A$. minutum cells in larvae digestive tract and feces was checked under light microscope. 


\subsection{Larval survival and settlement}

252 All the tanks were drained and the total number of larvae was determined at $22 \mathrm{dpf}$ (Fig.

253 1), when $\geq 50 \%$ of larvae reached the eyed larvae stage (morphological competence for 254 metamorphosis) in the control tanks (non-exposed oysters derived from control parents). Each 255 larval population was transferred to a PVC container with a $125-\mu \mathrm{m}$ nylon mesh base (in 256 triplicate per treatment), maintained in a flow-through system $\left(9 \mathrm{~L} \mathrm{~h}^{-1}, 30 \% \mathrm{~h}^{-1}\right.$ seawater 257 renewal, $21^{\circ} \mathrm{C}, 35 \mathrm{PSU}$ ) and fed the Tiso/Chaeto diet as described previously. After 7 days 258 (29 dpf), the number of remaining swimming larvae, dead larvae, and larvae settled on tank walls and sieve were counted (Fig. 1). The percentage of survival during the settlement step was evaluated as: total number of alive larvae at $29 \mathrm{dpf} \times 100 /$ total number of larvae initially

261 stocked at $22 \mathrm{dpf}$. The larval settlement was evaluated as: number of settled larvae at $29 \mathrm{dpf} \times$ $262100 /$ total number of alive larvae at $29 \mathrm{dpf}$.

\subsection{Statistical analyses}

264 Statistical analyses were performed using R version 3.2.2 (R Core Team, 2012). All values are expressed as mean \pm standard error (SE). Differences were considered significant when $p$ $<0.05$. Differences in oyster algal consumption were evaluated using repeated measures

267 ANOVA, where 'algal exposure' and 'day' were fixed factors (Huvet et al., 2015). 268 Comparison for oyster gonadal maturation and occupation index between the two algal treatments were investigated for each sampling time using Mann-Whitney $\mathrm{U}$ test and $t$-test, respectively. Results of oyster condition index, gonadal maturation and occupation were

271 pooled for the 3 tanks of each algal treatment, after verifying there were no statistical

272 differences between tanks using one-way ANOVA, Fisher's exact test, and $t$-test, 273 respectively. Number of oocytes, and gamete parameters were compared using $t$-test. 274 Comparison for PST content in oyster digestive glands between sampling times was assessed 
homoscedasticity assumption was not met. To determine any significant differences between 'parental exposure', and 'larval exposure' on larvae, larval length, survival, and settlement were analyzed using a two-way ANOVA, where 'parental exposure' and 'larval exposure' were fixed and orthogonal factors. Levene's test was used to determine any heterogeneity of variances and data were transformed if significant. In case of a significant interaction between the two factors, a Tukey HSD was used to detect differences among means.

\section{Results}

\subsection{Oyster algal consumption, gonad development and biochemical composition}

No mortality was observed in adult oysters during the experiment. A significantly higher algal consumption $(+10 \%, \mathrm{~F}=66.93, \mathrm{df}=1, p<0.01$; two-way ANOVA $)$ was observed over the whole experiment for oysters exposed to A. minutum $\left(3.32 \times 10^{9} \pm 5.72 \times 10^{7} \mu \mathrm{m}^{3}\right.$ of algae oyster $\left.{ }^{-1} \mathrm{~h}^{-1}\right)$ compared to control oysters $\left(3.02 \times 10^{9} \pm 5.87 \times 10^{7} \mu \mathrm{m}^{3}\right.$ of algae oyster ${ }^{-1}$ $\left.\mathrm{h}^{-1}\right)$ when averaged over the whole experiment. There was a significant effect of date $(\mathrm{F}=$ 114.88, $\mathrm{df}=47, p<0.001$; two-way ANOVA), and a date-exposure interaction on algal consumption $(\mathrm{F}=4.92, \mathrm{df}=47, p<0.001$; two-way ANOVA $)$. No difference $(\mathrm{t}=0.39, \mathrm{df}=$ 28; $t$-test) in condition index was observed between exposed and control oysters at the end of the conditioning ( $10.8 \pm 0.5$ and $10.6 \pm 0.4$, respectively).

Gonadal maturation was not different between exposed and control oysters during broodstock conditioning (Table S1). At T6, all oysters were ripe (stage 3) in both treatments and gonadal occupation index was not significantly different between exposed $(61.5 \pm 3.0 \%)$ and control $(55.1 \pm 3.1 \%)$ oysters (Table S1). The total number of oocytes collected by stripping at the time of breeding was not significantly different $(\mathrm{t}=-1.06, \mathrm{df}=4 ; t$-test $)$ in exposed $\left(5.4 \times 10^{6} \pm 0.4\right)$ and control $\left(6.5 \times 10^{6} \pm 0.9\right)$ females

Gonad lipid content was higher $(+55 \%, \mathrm{t}=3.98, \mathrm{df}=4, p<0.05 ; t$-test $)$ in exposed males $(17.0 \pm 1.5 \%)$ than in controls $(10.9 \pm 0.4 \%)$, but protein and carbohydrate contents were not 
301

302

303

304

305

306

307

308

309

different (Table S2). No significant difference in oocyte biochemical composition was observed between both treatments (Table S2).

\subsection{Gamete quality}

Significantly lower percentage of motile spermatozoa $(-36 \%, \mathrm{t}=-2.94, \mathrm{df}=9, p<0.05 ; t$ test) was observed in exposed oysters $(30 \pm 5 \%)$ compared to control $(48 \pm 3 \%)$ oysters (Table S3). Spermatozoa velocity and ATP content were similar between the two treatments (Table S3). Oocyte diameter and circularity did not differ between treatments (Table S3). Oocyte and spermatozoa cellular characteristics measured by flow cytometry were similar in exposed and control oysters (Table S3).

\subsection{Paralytic shellfish toxin content}

The PST content in the digestive glands of exposed oysters was $10.9 \pm 0.5,26.7 \pm 1.6$, and $19.3 \pm 3.5 \mu \mathrm{g}$ STX $100 \mathrm{~g}^{-1}$ of DG after 2 (T2), 4 (T4), and 6 weeks of conditioning (T6), respectively. The PST content in the digestive glands of exposed oysters was higher $(p<0.05$; Kruskal-Wallis $)$ at T7 $\left(131.3 \pm 22.4 \mu \mathrm{g}\right.$ STX $100 \mathrm{~g}^{-1}$ of DG) and T8 $(52.5 \pm 5.0 \mu \mathrm{g}$ STX 100 $\mathrm{g}^{-1}$ of DG) (i.e. after the mimicked A. minutum bloom at $10^{3}$ cells per $\mathrm{mL}$ ) than at $\mathrm{T} 2$, $\mathrm{T} 4$ and T6.

The PST content in exposed oyster gonads measured at T8 was $1.8 \pm 0.1 \mu \mathrm{g}$ STX $100 \mathrm{~g}^{-1}$ wet gonad weight $(n=3$ pools of $4-6$ oysters) for exposed males, and $0.3 \pm 0.1 \mu \mathrm{g}$ STX 100 $\mathrm{g}^{-1}$ wet oocytes weight ( $\mathrm{n}=3$ pools of $9-10$ oysters) for exposed females, corresponding to 3.3 $\%$ and $0.6 \%$ of the PST content measured in the digestive glands, respectively.

\subsection{Larval length, survival and settlement}

Larval length was significantly affected by both parental and larval exposures to $A$. minutum (Fig. 2). Larval and parental exposures had significant independent $(\mathrm{F}=39.04$, df $=$ $1, p<0.001$, and $\mathrm{F}=7.134, \mathrm{df}=1, p<0.05$, respectively; two-way ANOVA) and interactive effects $(\mathrm{F}=15.22$, df $=1, p<0.01$; two-way ANOVA) upon larval length at $22 \mathrm{dpf}$ (Fig. 3Fig. 
3A). At $22 \mathrm{dpf}$, non-exposed larvae derived from exposed parents $(248.3 \pm 11.3 \mu \mathrm{m})$ were

significantly smaller $(-15 \%, p<0.01$; Tukey HSD) compared to non-exposed larvae derived from control parents $(293.2 \pm 3.7 \mu \mathrm{m})$.

Exposed larvae derived from control parents $(223.9 \pm 4.4 \mu \mathrm{m})$ were smaller $(-24 \%, p<$

0.001; Tukey HSD) compared to non-exposed larvae derived from control parents, whereas the length of exposed larvae derived from exposed parents $(232.3 \pm 5.1 \mu \mathrm{m})$ was not significantly different $(-6 \%)$ from non-exposed larvae derived from exposed parents (Fig. 3A). The length of exposed larvae derived from exposed parents was, however, lower (-20\%, $p<0.01$; Tukey HSD) than non-exposed larvae derived from control parents (Fig. 3A).

Parental exposure, but not larval exposure, significantly affected larval survival during the settlement step (Fig. 3B, $\mathrm{F}=8.21$, df $=1, p<0.05$; two-way ANOVA). Larvae derived from exposed parents had reduced survival $(33.6 \pm 10.8 \%$ and $32.0 \pm 7.1 \%$ for non-exposed and exposed larvae, respectively) compared to larvae derived from control parents $(67.3 \pm 4.2 \%$ and $41.2 \pm 6.3 \%$ for non-exposed and exposed larvae, respectively; Fig. 3B).

Larval exposure, but not parental exposure, significantly reduced larval settlement $(\mathrm{F}=$ 8.77, df $=1, p<0.05$; two-way ANOVA, Fig. 3C). Settlement rates were $3.9 \% \pm 0.3$ and 5.1 $\% \pm 1.8$ for exposed larvae, and $11.9 \% \pm 1.1$ and $30.0 \% \pm 10.9$ for non-exposed larvae derived from control and exposed parents, respectively (Fig. 3C).

344 Ingestion tests on control larvae indicated that eyed larvae fed on A. minutum, as these 345 algal cells were observed in the intestine and feces of eyed larvae (Fig. 4C-E). Conversely, 346 ingestion was not observed with early umbonate larvae due to the relative large cell size of $A$. 347 minutum $(23-29 \mu \mathrm{m})$ (Fig. 4A, B).

\section{Discussion}

Coastal areas regularly experience few days to several weeks of HAB during bivalve reproductive season (Guallar et al., 2017). This experiment was designed to assess the 
consequences of the toxic dinoflagellate Alexandrium minutum upon reproduction, early development, and settlement of Crassostrea gigas oysters, an environmentally and economic important species.

\subsection{Presence of A. minutum modifies feeding of maturing oysters}

Algal consumption was significantly higher for oysters exposed to A. minutum than for control oysters over the whole experiment. Pousse et al. (2018) applied a mechanistic model based on Dynamic Energy Budget theory to the data of the present study, coupling the kinetics of PST accumulation and bioenergetics in $C$. gigas. They evidenced that toxicant stress provoked by A. minutum affected the energy balance of oysters, more energy being needed for tissue damage repair and detoxification of toxic substances produced by $A$. minutum. Exposed adult oysters would therefore increase their food consumption to adjust energy intake. Such modification of feeding activity was observed in oysters exposed to polystyrene microspheres to compensate digestive interference caused by plastic particles (Sussarellu et al., 2016) and has been proposed for female copepods Acartia (Acartiura) clausi exposed to A. minutum (previously A. lusitanicum) (Dutz, 1998).

Under our experimental conditions of dual feeding with A. minutum and non-toxic Tiso/Chaeto algae, the higher feeding rate seemed to partly counterbalance the higher energy demand due to A. minutum. Coupled with active detoxification of toxins (Fabioux et al., 2015), this could explain the absence of major visible effects on gonadal maturation and reproductive effort. However, the lower percentage of motile spermatozoa in oysters exposed to A. minutum still suggests that this response might not be sufficient to overcome PST toxicity on broodstock.

\subsection{Broodstock exposure to A. minutum affected quality of gametes}

In male oysters, exposure to A. minutum decreased the percent of motile spermatozoa. Haberkorn et al. (2010b) evidenced that a short acute exposure of mature oysters to $A$. 
minutum reduced spermatozoa motility and ATP content, and altered structural and reserve

377

378

379

380

381

382

lipids of the digestive gland. In the present study, neither decreased ATP content nor sperm mortality can explain this reduced motility. Total lipid content in male gonads of exposed oysters increased maybe reflecting modifications in lipid metabolism. Lipids are key component of cellular membranes of spermatozoa and modifications in lipid metabolism could be associated with changes in gamete features. PST bind to voltage-gated $\mathrm{Na}^{+}$channels with high affinity and interact, to a lesser extent, with $\mathrm{Ca}^{2+}$ and $\mathrm{K}^{+}$channels, modifying ionic fluxes into cells (Llewellyn, 2006) and associated metabolic pathways (Mat et al., 2018). Spermatozoa motility in Pacific oysters is a key factor for reproduction and notably depends on concentrations of ions including $\mathrm{K}^{+}, \mathrm{Ca}^{2+}$ and $\mathrm{Na}^{+}$(Alavi et al., 2014). Indeed, the percentage of motile sperm is drastically reduced in $\mathrm{Na}^{+}$-free seawater (Boulais et al., 2018). In the present study, PST could be responsible for the decreased motility observed in spermatozoa through membrane alterations or ionic fluxes changes. In the field, the fertilization rate of oysters could be impaired by fewer motile spermatozoa with negative consequences on recruitment, as proposed for another free-spawning invertebrate, the sea urchin exposed to high doses of cadmium (Au et al., 2001). The present experimental conditions probably hide this negative effect, as spermatozoa are put in excess compared to oocytes for in vitro fertilization, in a small limited volume, increasing pairing probability compared to natural conditions.

\subsection{Broodstock exposure to A. minutum affected offspring growth and survival}

Broodstock exposure to A. minutum decreased offspring growth and induced higher mortality in larvae during the settlement period. Intracellular PST initially accumulate in the digestive gland of bivalves following algal cell lysis and are then transferred into other organs, including gonads (Bricelj and Shumway, 1998). In this study, PST was detected in oocytes $\left(0.3 \pm 0.1 \mu \mathrm{g}\right.$ STX $100 \mathrm{~g}^{-1}$ wet oocytes weight $)$ and male gonad $(1.8 \pm 0.1 \mu \mathrm{g}$ STX 
$100 \mathrm{~g}^{-1}$ wet gonad weight), which is consistent with PST content observed in oocytes of

mature oysters exposed to a natural A. minutum bloom (Hermabessiere et al., 2016).

403

404

405

406

407

408

409

Crassostrea virginica larvae derived from oysters naturally exposed to Karenia brevis showed significantly higher mortalities and smaller length than larvae derived from non-exposed oysters, suggesting that these negative effects on larval development may be due to the presence of brevetoxins in oocytes (Rolton et al., 2018, 2016). In the present study, toxic effects on the next generation could thus originate from deleterious effect of PST transferred to offspring via gametes. Maternal effects in eggs influence embryogenesis and larval development (Bayne, 2017). PST may also have resulted in functional cell damage during the process of gametogenesis with consequences on development of offspring. Larval physiology could be affected even later during development and settlement like in the present study.

\subsection{Larval growth and settlement are affected by direct exposure to A. minutum}

A substantial alteration of larval growth was observed for larvae exposed to A. minutum, both derived from control and exposed adult oysters. Alexandrium toxicity comes from intracellular PST but also from bioactive extracellular compounds (BECs) produced and excreted in the surrounding water by some Alexandrium strains, such as the A. minutum strain tested in this study (Borcier et al., 2017; Castrec et al., 2018; Long et al., 2018). These BECs can be allelopathic, cytotoxic, haemolytic, or ichthyotoxic (Arzul et al., 1999; Ford et al., 2008; Lelong et al., 2011; Mardones et al., 2015), however, their molecular structures remain largely unknown (Ma et al., 2011). This detrimental effect of $A$. minutum on larvae could be attributed sequentially to BEC and PST during development.

Toxic effects on small $C$. gigas larvae (D-larvae to larvae $<150 \mu \mathrm{m}$ ) which are unable to feed on A. minutum could not be related to PST toxicity arising from algal cell consumption, but rather arise from BECs. These bioactive substances produced by Alexandrium minutum mainly exert their action by direct contact with external tissues, e.g. the gills (Borcier et al., 
2017; Castrec et al., 2018) or cells, e.g. gametes (Le Goïc et al., 2014). These BECs could be cytotoxic to the velum, the feeding and swimming organ of the larvae, thereby reducing energy uptake and subsequent larval growth. Similarly, the toxic effects of A. minutum and A. ostenfeldii on M. edulis larvae observed by De Rijcke et al. (2016) could mainly result from extracellular bioactive substances, as suggested by the authors. This hypothesis was also suggested by Banno et al. (2018) who identified some unknown bioactive compounds as responsible for the decrease of sperm mobility and egg viability of oysters $P$. fucata martensii exposed to two Alexandrium species.

The PST probably become harmful from the moment larvae are able to ingest A. minutum cells. In this study, $C$. gigas eyed larvae (mean length \pm SD: $304 \pm 15 \mu \mathrm{m}$ ) ingested $A$. minutum cells. Veliger larvae (> $200 \mu \mathrm{m}$ ) of the oyster $C$. virginica fed preferably on large food material $(22$ to $30 \mu \mathrm{m})$ in the presence of large cell dinoflagellate bloom (Baldwin, 1995), suggesting that oyster larvae (> $200 \mu \mathrm{m}$ ) likely fed on A. minutum in the present study. Thus, both the PST accumulated through A. minutum consumption and the BECs could have contributed to the adverse effects on growth at the end of the larval development. This hypothesis supports the findings of $\mathrm{Mu}$ and $\mathrm{Li}$ (2013) who suggested that the reduced growth of early umbonate larvae of $C$. gigas following a 4-day exposure to $3 \times 10^{2}$ cells $\mathrm{mL}^{-1}$ of $A$. catenella might relate to both PST and unknown toxins produced by A. catenella.

\section{Larval exposure to A. minutum also altered the settlement of oyster larvae. Larval mortality} does not explain the reduced settlement in exposed larvae. The decreased settlement could either result from the lagged growth observed after 22 days of exposure, as most exposed larvae did not reach the competence for settlement and metamorphosis, and/or from altered physiology caused by $A$. minutum toxins. Similarly, the activity of Japanese pearl oyster $(P$. fucata martensii) pre-settling larvae was decreased when exposed to Alexandrium affine and
A. catenella, at $2.5 \times 10^{2}$ cells $\mathrm{mL}^{-1}$ and 10 cells $\mathrm{mL}^{-1}$, respectively (Basti et al., 2015). This 
451

452

453

454

456

457

458

459

effect was attributed to non-PST metabolites with potent lytic activity produced by the nonPST A. affine or to the PST produced by A. catenella, following ingestion of algal cells, leading to paralysis and/or altered cellular homeostasis (Basti et al., 2015).

\subsection{Broodstock conditioning influenced larval response to A. minutum exposure}

In the present study, growth of larvae derived from exposed parents was less affected by $A$. minutum exposure than growth of larvae derived from non-exposed oysters. This result suggests that parental exposure to A. minutum may have led to an improved capacity to cope with the stress caused by A. minutum exposure. Similarly, exposure of adult Sydney rock oysters to elevated $\mathrm{pCO}_{2}$ improved the capacity of their offspring to regulate extracellular $\mathrm{pH}$ at elevated $\mathrm{pCO}_{2}$ (Parker et al., 2012). Boullot et al. (2018) revealed that the sensitivity of $C$. gigas nerves to saxitoxin was decreased when oysters had been previously exposed to PSTproducing A. minutum. It can be hypothesized that larvae derived from PST-containing gametes produced by exposed parents may be less sensitive to PST during larval development.

\section{Conclusions}

Successful reproduction is essential for the sustainability of marine populations. This study demonstrates that long term exposure of adult oysters to A. minutum during gametogenesis affected spermatozoa motility, and reduced growth and survival of the subsequent offspring. The present laboratory experiment also evidenced that direct A. minutum exposure during oyster embryo-larval development significantly altered growth and settlement of larvae. These effects of A. minutum blooms on oyster reproduction are likely to compromise recruitment of benthic post-larvae of $C$. gigas by slowing down growth, prolonging the time larvae remain in the seawater column, thus making them more vulnerable to predation. Further research is needed to investigate potential long term effects on marine bivalve populations by studying the consequences of recurrent Alexandrium blooms over multiple generations. 
476

\section{Acknowledgments}

477 This project was supported by the National Research Agency ANR CESA, which founded 478 the ACCUTOX project ANR-13-CESA-0019 (2013-2017). This work was also co-funded by 479 grants from the Regional Council of the Région Bretagne and Brest Métropole. The authors 480 gratefully acknowledge all the colleagues who provided a valuable help during the 481 experiment, dissections, discussions and advices: Guillaume Rivière, Christian Mingant, 482 Matthias Huber, Jacqueline Le Grand, Ashley Taylor Demey, Emilien Pousse, and Claudie 483 Quéré. 


\begin{tabular}{|c|c|c|c|c|c|c|c|}
\hline \begin{tabular}{|l|} 
T0 \\
\end{tabular} & \begin{tabular}{|l|}
$\mathrm{T} 2$ \\
\end{tabular} & T4 & \begin{tabular}{|l|} 
T6 \\
\end{tabular} & $\mathrm{T} 7$ & $\mathrm{~T} 8$ & $48 \mathrm{hpf}$ & $22 \mathrm{dpf}$ \\
\hline \multicolumn{5}{|c|}{ oodstock conditionning } & & \multicolumn{2}{|c|}{ Larval rearing } \\
\hline
\end{tabular}

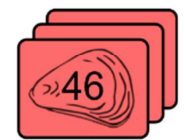

Exposed

A. $m$.

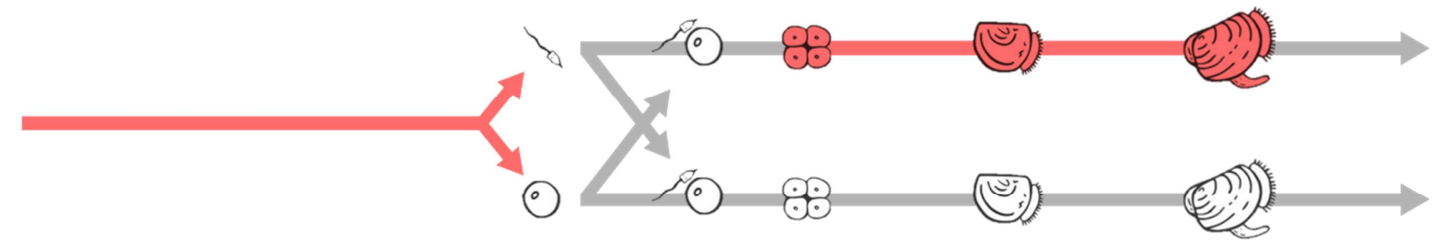

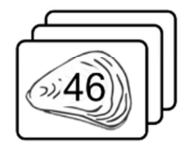

Control

H. t.

Adult oysters

50L tanks;

3 replicate tanks;

46 oysters tank ${ }^{-1}$

Tiso/Chaeto feeding

8 weeks

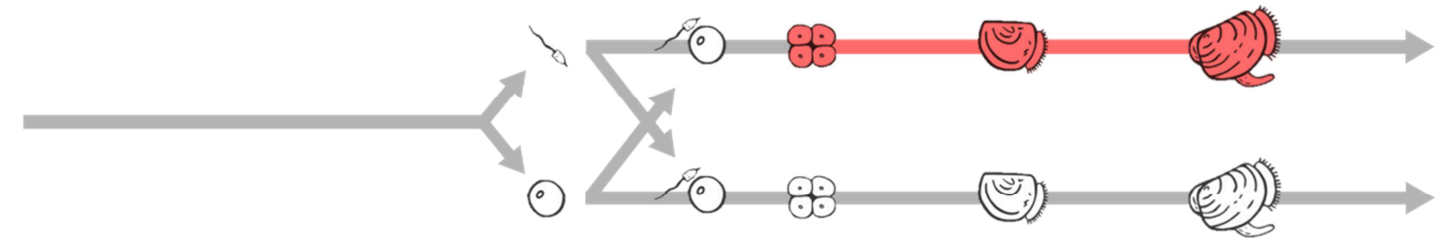

$\begin{array}{lll}\text { Strip } & \text { Fertilization } & \text { Embryo } \\ \text { spawing } & \text { Until 1.5 hpf } & 150 \mathrm{~L} \text { tanks; } \\ \text { Pooled from } & & \text { Until D-larvae } \\ \text { the 3 replicate } & & \text { stage (48 hpf) }\end{array}$

tanks

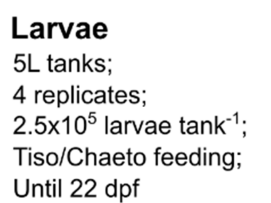

ttlement

30L tanks; 3 replicates;

Tiso/Chaeto feeding; Until $29 \mathrm{dpf}$

\section{$484 \quad$ Figures}

Fig. 1. Flow chart of the experiment. For broodstock conditioning, oysters in red are exposed to the toxic Alexandrium minutum (A. m.), whereas oysters in white are fed with non-toxic Heterocapsa triquetra $($ H. t. $=$ control treatment). During adult oyster exposure, oysters were sampled every two weeks (T0, T2, T4, T6 and T8) for PST accumulation and histological analyses to study gametogenesis. Gamete cellular analyses were conducted on oysters sampled after 7 weeks of exposure (T7). For larval rearing, embryos and larvae in red are exposed to the toxic A. minutum, whereas stages in white are non-exposed. Tiso/Chaeto feeding: Tisochrysis lutea and Chaetoceros sp. feeding ad libitum; hpf: hours post-fertilization; dpf: days post-fertilization. (For interpretation of the references to color in this figure legend, the reader is referred to the web version of this article.) 


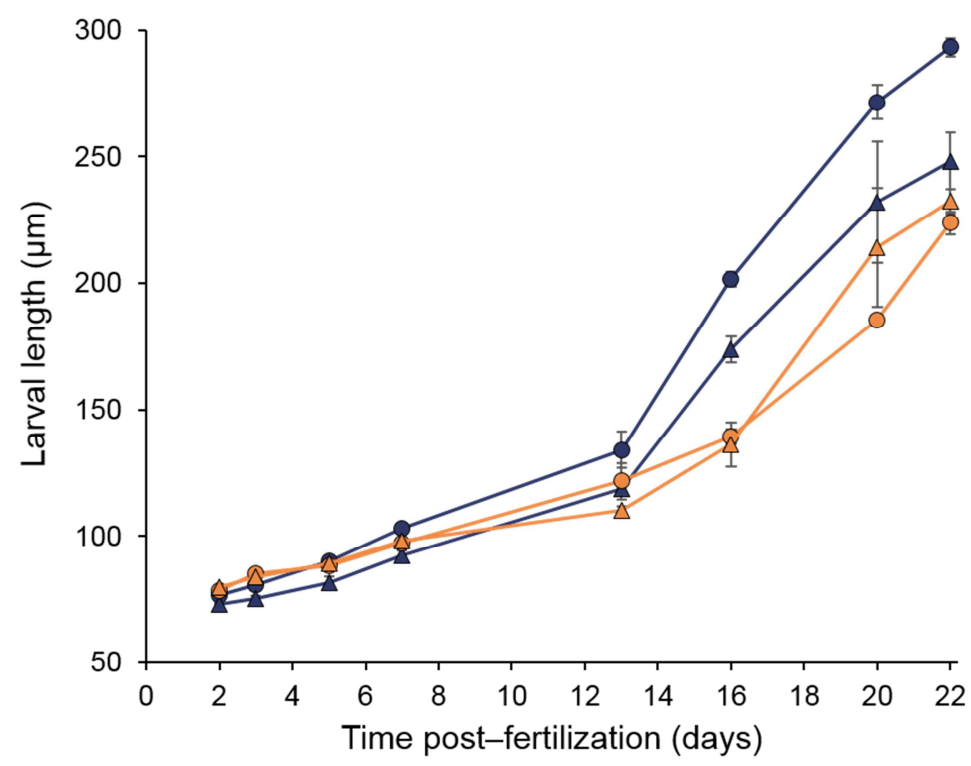

$\rightarrow$ Non-exposed larvae derived from control parents (controls)

$\triangle$ Non-exposed larvae derived from exposed parents

- - Exposed larvae derived from control parents

$\triangle$ Exposed larvae derived from exposed parents

Fig. 2. Larval length from D-larvae up to metamorphosis of the controls (non-exposed larvae derived from control parents) and the three other combination of parental and larval exposures. Larval groups were obtained by crossing gametes collected from adult Crassostrea gigas exposed to the non-toxic Heterocapsa triquetra (control parents) and from oysters exposed to Alexandrium minutum (exposed parents), and then exposing the offspring continuously to A. minutum (exposed larvae) or not (nonexposed larvae). Mean $\pm \mathrm{SE}, \mathrm{n}=3$. 

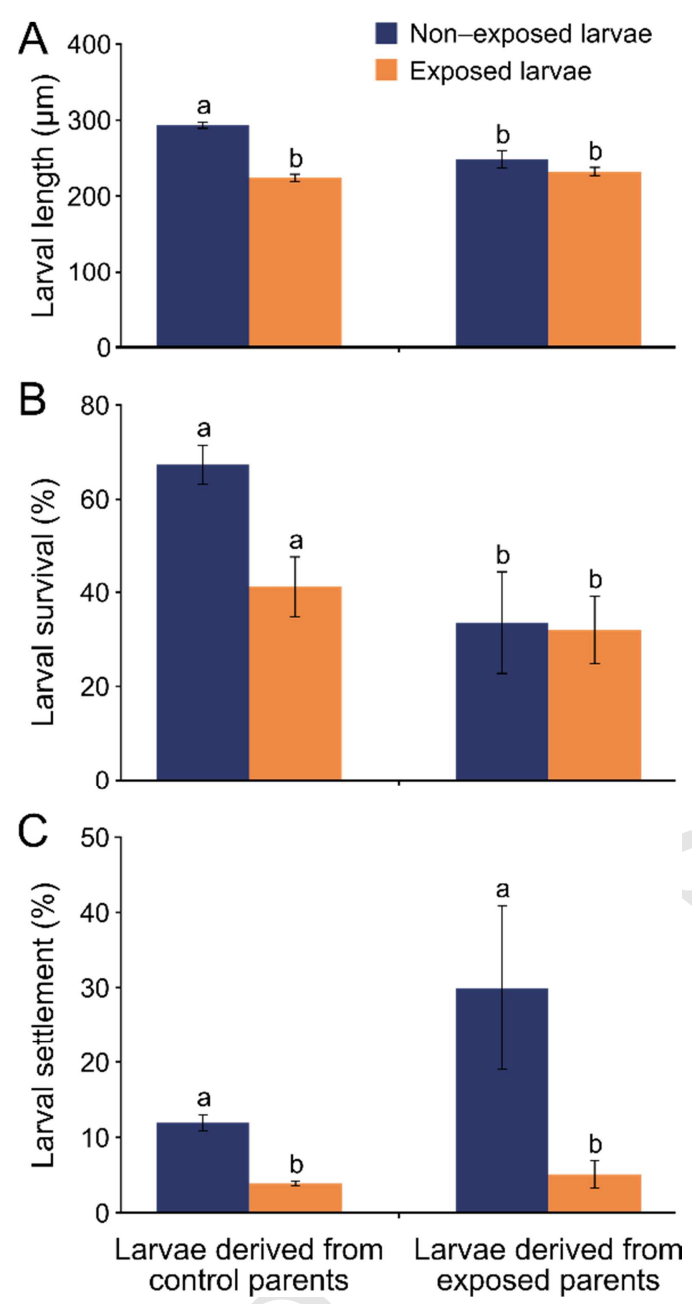

500 Fig. 3. Larval length 22 days post-fertilization (dpf) (A), survival (B) and settlement (C) of C. gigas 501 larvae, non-exposed or exposed to A. minutum, derived from A. minutum exposed parents or control parents. Survival is estimated as the total number of alive larvae 29 dpf divided by number of larvae initially stocked at $22 \mathrm{dpf}$. Settlement is calculated as the number of settled larvae at $29 \mathrm{dpf}$ divided by the total number of live larvae at $29 \mathrm{dpf}$. Mean $\pm \mathrm{SE}, \mathrm{n}=3$. Letters denote significant groupings $(p<$ 0.05; two-way ANOVA and Tukey HSD). 


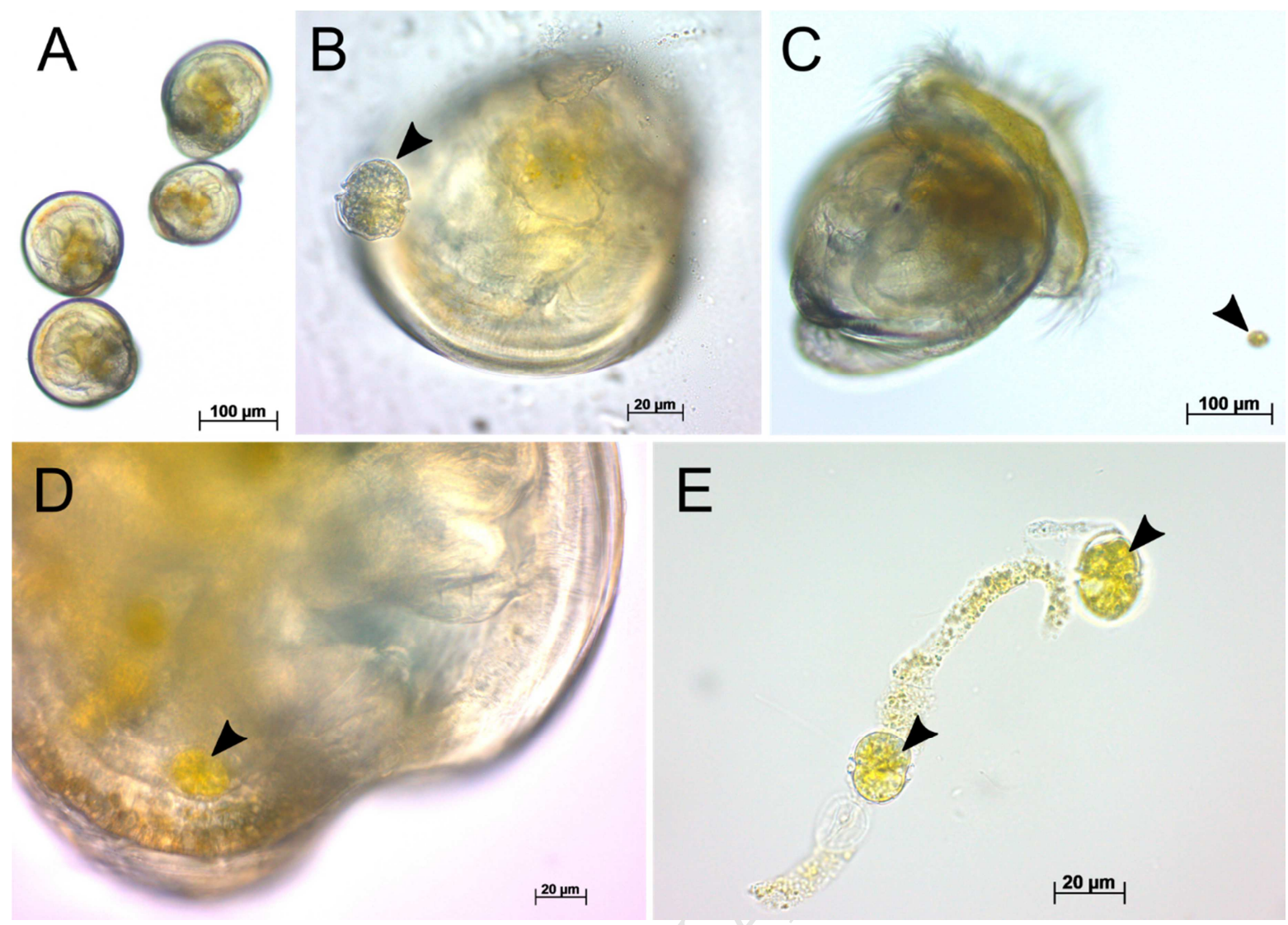

Fig. 4. Capacity of control $C$. gigas larvae to ingest $A$. minutum. Light micrographs. Umbonate larvae (A, B; mean shell length $150 \pm 22 \mu \mathrm{m}$ ) were unable to ingest $A$. minutum cells due to their relative large size (23-29 $\mu \mathrm{m})$, whereas eyed larvae (C-E; mean shell length $304 \pm 15 \mu \mathrm{m}$ ) fed on A. minutum: algal cells were observed in the intestine (D) and fecal pellets (E). Black arrows indicate A. minutum 510 cells. 


\section{References}

Alavi, S.M.H., Matsumura, N., Shiba, K., Itoh, N., Takahashi, K.G., Inaba, K., Osada, M., 2014. Roles of extracellular ions and $\mathrm{pH}$ in 5-HT-induced sperm motility in marine bivalve. Reproduction 147, 331-345. https://doi.org/10.1530/REP-13-0418

Anderson, D.M., Alpermann, T.J., Cembella, A.D., Collos, Y., Masseret, E., Montresor, M., 2012a. The globally distributed genus Alexandrium: Multifaceted roles in marine ecosystems and impacts on human health. Harmful Algae 14, 10-35. https://doi.org/10.1016/j.hal.2011.10.012

Anderson, D.M., Cembella, A.D., Hallegraeff, G.M., 2012b. Progress in understanding harmful algal blooms (HABs): Paradigm shifts and new technologies for research, monitoring and management. Annu. Rev. Mar. Sci. 4, 143-176. https://doi.org/10.1146/annurev-marine-120308-081121

Arzul, G., Seguel, M., Guzman, L., Erard-Le Denn, E., 1999. Comparison of allelopathic properties in three toxic Alexandrium species. J. Exp. Mar. Biol. Ecol. 232, 285-295. https://doi.org/10.1016/S0022-0981(98)00120-8

Asmani, K., Petton, B., Le Grand, J., Mounier, J., Robert, R., Nicolas, J.-L., 2016. Establishment of microbiota in larval culture of Pacific oyster, Crassostrea gigas. Aquaculture 464, 434-444. https://doi.org/10.1016/j.aquaculture.2016.07.020

Au, D.W.T., Lee, C.Y., Chan, K.L., Wu, R.S.S., 2001. Reproductive impairment of sea urchins upon chronic exposure to cadmium. Part I: Effects on gamete quality. Environ. Pollut. 111, 1-9. https://doi.org/10.1016/S0269-7491(00)00035-X

Baldwin, B.S., 1995. Selective particle ingestion by oyster larvae (Crassostrea virginica) feeding on natural seston and cultured algae. Mar. Biol. 123, 95-107. https://doi.org/10.1007/BF00350328

Banno, K., Oda, T., Nagai, K., Nagai, S., Tanaka, Y., Basti, L., 2018. Deleterious effects of harmful dinoflagellates and raphidophytes on egg viability and spermatozoa swimming velocity in the Japanese pearl oyster Pinctada fucata martensii. J. Shellfish Res. 37, 41-48. https://doi.org/10.2983/035.037.0103

Basti, L., Nagai, S., Go, J., Okano, S., Nagai, K., Watanabe, R., Suzuki, T., Tanaka, Y., 2015. Differential inimical effects of Alexandrium spp. and Karenia spp. on cleavage, hatching, and two larval stages of Japanese pearl oyster Pinctada fucata martensii. Harmful Algae 43, 1-12. https://doi.org/10.1016/j.hal.2014.12.004

Bayne, B., 2017. Reproduction, in: Bayne, B. (Ed.), Biology of Oysters, Developments in Aquaculture and Fisheries Science. Elsevier, San Diego, CA, pp. 565-701. https://doi.org/10.1016/B978-0-12-803472-9.00009-1

Bligh, E.G., Dyer, W.J., 1959. A rapid method of total lipid extraction and purification. Can. J. Biochem. Physiol. 37, 911-917. https://doi.org/10.1139/059-099

Borcier, E., Morvezen, R., Boudry, P., Miner, P., Charrier, G., Laroche, J., Hegaret, H., 2017. Effects of bioactive extracellular compounds and paralytic shellfish toxins produced by Alexandrium minutum on growth and behaviour of juvenile great scallops Pecten maximus. $\quad$ Aquat. Toxicol. $184, \quad 154$. https://doi.org/10.1016/j.aquatox.2017.01.009

Boulais, M., Corporeau, C., Huvet, A., Bernard, I., Quéré, C., Quillien, V., Fabioux, C., Suquet, M., 2015a. Assessment of oocyte and trochophore quality in Pacific oyster, Crassostrea gigas. Aquaculture 437, 201-207. https://doi.org/10.1016/j.aquaculture.2014.11.025

Boulais, M., Soudant, P., Le Goïc, N., Quéré, C., Boudry, P., Suquet, M., 2017. ATP content and viability of spermatozoa drive variability of fertilization success in the Pacific 
oyster (Crassostrea gigas). Aquaculture 479, 114-119. https://doi.org/10.1016/j.aquaculture.2017.05.035

Boulais, M., Soudant, P., Le Goïc, N., Quéré, C., Boudry, P., Suquet, M., 2015b. Involvement of mitochondrial activity and OXPHOS in ATP synthesis during the motility phase of spermatozoa in the Pacific oyster, Crassostrea gigas. Biol. Reprod. biolreprod.115.128538. https://doi.org/10.1095/biolreprod.115.128538

Boulais, M., Suquet, M., Arsenault-Pernet, E.J., Malo, F., Queau, I., Pignet, P., Ratiskol, D., Grand, J.L., Huber, M., Cosson, J., 2018. pH controls spermatozoa motility in the Pacific oyster (Crassostrea gigas). Biol. Open 7, bio031427. https://doi.org/10.1242/bio.031427

Boullot, F., Fabioux, C., Hegaret, H., Soudant, P., Boudry, P., Benoit, E., 2018. Assessment of saxitoxin sensitivity of nerves isolated from the Pacific oyster, Crassostrea gigas, exposed to Alexandrium minutum. Toxicon 149, 93. https://doi.org/10.1016/j.toxicon.2017.12.025

Bricelj, V.M., Greene, M., Lee, J., Cembella, A., 1993. Growth of the blue mussel Mytilus edulis on toxic Alexandrium fundyense and effects of gut passage on dinoflagellate cells, in: T.J. Smayda, Y. Shimizu (Eds.), Toxic Phytoplankton Blooms in the Sea, Elsevier Science Publishers B. V. pp. 371-376.

Bricelj, V.M., Shumway, S.E., 1998. Paralytic shellfish toxins in bivalve molluscs: Occurrence, transfer kinetics, and biotransformation. Rev. Fish. Sci. 6, 315-383. https://doi.org/10.1080/10641269891314294

Castrec, J., Soudant, P., Payton, L., Tran, D., Miner, P., Lambert, C., Le Goïc, N., Huvet, A., Quillien, V., Boullot, F., Amzil, Z., Hégaret, H., Fabioux, C., 2018. Bioactive extracellular compounds produced by the dinoflagellate Alexandrium minutum are highly detrimental for oysters. Aquat. Toxicol. 199, 188-198. https://doi.org/10.1016/j.aquatox.2018.03.034

Chapelle, A., Le Gac, M., Labry, C., Siano, R., Quere, J., Caradec, F., Le Bec, C., Nezan, E., Doner, A., Gouriou, J., 2015. The Bay of Brest (France), a new risky site for toxic Alexandrium minutum blooms and PSP shellfish contamination. Harmful Algae News 51, 4-5.

Da Costa, F., Petton, B., Mingant, C., Bougaran, G., Rouxel, C., Quéré, C., Wikfors, G. h., Soudant, P., Robert, R., 2015. Influence of one selected Tisochrysis lutea strain rich in lipids on Crassostrea gigas larval development and biochemical composition. Aquac. Nutr. 22, 813-836. https://doi.org/10.1111/anu.12301

De Rijcke, M., Van Acker, E., Nevejan, N., De Schamphelaere, K.A.C., Janssen, C.R., 2016. Toxic dinoflagellates and Vibrio spp. act independently in bivalve larvae. Fish Shellfish Immunol. 57, 236-242. https://doi.org/10.1016/j.fsi.2016.08.027

Dubois, M., Gilles, K.A., Hamilton, J.K., Rebers, P.A.T., Smith, F., 1956. Colorimetric method for determination of sugars and related substances. Anal. Chem. 28, 350-356.

Dutz, J., 1998. Repression of fecundity in the neritic copepod Acartia clausi exposed to the toxic dinoflagellate Alexandrium lusitanicum: Relationship between feeding and egg production. Mar. Ecol. Prog. Ser. 175, 97-107.

Ekstrom, J.A., Suatoni, L., Cooley, S.R., Pendleton, L.H., Waldbusser, G.G., Cinner, J.E., Ritter, J., Langdon, C., van Hooidonk, R., Gledhill, D., Wellman, K., Beck, M.W., Brander, L.M., Rittschof, D., Doherty, C., Edwards, P.E.T., Portela, R., 2015. Vulnerability and adaptation of US shellfisheries to ocean acidification. Nat. Clim. Change 5, 207-214. https://doi.org/10.1038/nclimate2508

Fabioux, C., Huvet, A., Le Souchu, P., Le Pennec, M., Pouvreau, S., 2005. Temperature and photoperiod drive Crassostrea gigas reproductive internal clock. Aquaculture 250, 458-470. https://doi.org/10.1016/j.aquaculture.2005.02.038 
Fabioux, C., Sulistiyani, Y., Haberkorn, H., Hégaret, H., Amzil, Z., Soudant, P., 2015. Exposure to toxic Alexandrium minutum activates the detoxifying and antioxidant systems in gills of the oyster Crassostrea gigas. Harmful Algae 48, 55-62. https://doi.org/10.1016/j.hal.2015.07.003

FAO, 2018. Fisheries and aquaculture information and statistics service, global aquaculture production statistics 1950-2016. http://www.fao.org/fishery/statistics/globalaquaculture-production/query/en. (Accessed 25 Mai 2018).

Ferreira, T., Rasband, W., 2012. ImageJ user guide. ImageJ/Fiji 1.

Ford, S.E., Bricelj, V.M., Lambert, C., Paillard, C., 2008. Deleterious effects of a nonPST bioactive compound(s) from Alexandrium tamarense on bivalve hemocytes. Mar. Biol. 154, 241-253. https://doi.org/10.1007/s00227-008-0917-z

Guallar, C., Bacher, C., Chapelle, A., 2017. Global and local factors driving the phenology of Alexandrium minutum (Halim) blooms and its toxicity. Harmful Algae 67, 44-60. https://doi.org/10.1016/j.hal.2017.05.005

Guillard, R.R.L., Hargraves, P.E., 1993. Stichochrysis immobilis is a diatom, not a chrysophyte. Phycologia 32, 234-236. https://doi.org/10.2216/i0031-8884-32-3-234.1

Haberkorn, H., Lambert, C., Le Goïc, N., Guéguen, M., Moal, J., Palacios, E., Lassus, P., Soudant, P., 2010a. Effects of Alexandrium minutum exposure upon physiological and hematological variables of diploid and triploid oysters, Crassostrea gigas. Aquat. Toxicol. 97, 96-108. https://doi.org/10.1016/j.aquatox.2009.12.006

Haberkorn, H., Lambert, C., Le Goïc, N., Moal, J., Suquet, M., Guéguen, M., Sunila, I., Soudant, P., 2010b. Effects of Alexandrium minutum exposure on nutrition-related processes and reproductive output in oysters Crassostrea gigas. Harmful Algae 9, 427-439. https://doi.org/10.1016/j.hal.2010.01.003

Haberkorn, H., Tran, D., Massabuau, J.-C., Ciret, P., Savar, V., Soudant, P., 2011. Relationship between valve activity, microalgae concentration in the water and toxin accumulation in the digestive gland of the Pacific oyster Crassostrea gigas exposed to Alexandrium minutum. Mar. Pollut. Bull. 62, 1191-1197. https://doi.org/10.1016/j.marpolbul.2011.03.034

Hallegraeff, G.M., 2010. Ocean climate change, phytoplankton community responses, and harmful algal blooms: A formidable predictive challenge. J. Phycol. 46, 220-235. https://doi.org/10.1111/j.1529-8817.2010.00815.x

Hattenrath-Lehmann, T.K., Ossiboff, R.J., Burnell, C.A., Rauschenberg, C.D., Hynes, K., Burke, R.L., Bunting, E.M., Durham, K., Gobler, C.J., 2017. The role of a PSPproducing Alexandrium bloom in an unprecedented diamondback terrapin (Malaclemys terrapin) mortality event in Flanders Bay, New York, USA. Toxicon 129, 36-43. https://doi.org/10.1016/j.toxicon.2017.02.006

Hermabessiere, L., Fabioux, C., Lassudrie, M., Boullot, F., Long, M., Lambert, C., Le Goïc, N., Gouriou, J., Le Gac, M., Chapelle, A., Soudant, P., Hégaret, H., 2016. Influence of gametogenesis pattern and sex on paralytic shellfish toxin levels in triploid Pacific oyster Crassostrea gigas exposed to a natural bloom of Alexandrium minutum. Aquaculture 455, 118-124. https://doi.org/10.1016/j.aquaculture.2016.01.001

Huvet, A., Béguel, J.-P., Cavaleiro, N.P., Thomas, Y., Quillien, V., Boudry, P., AlunnoBruscia, M., Fabioux, C., 2015. Disruption of amylase genes by RNA interference affects reproduction in the Pacific oyster Crassostrea gigas. J. Exp. Biol. 218, 17401747. https://doi.org/10.1242/jeb.116699

Kudela, R.M., Berdalet, E., Bernard, S., Burford, M., Fernand, L., Lu, S., Roy, S., Usup, G., Tester, P., Magnien, R., Anderson, D., Cembella, A.D., Chinain, M., Hallegraeff, G., Reguera, B., Zingone, A., Enevoldsen, H., Urban, E., 2015. Harmful Algal Blooms. A scientific summary for policy makers. IOC/UNESCO, Paris, France. 
Lassudrie, M., Soudant, P., Richard, G., Henry, N., Medhioub, W., da Silva, P.M., Donval, A., Bunel, M., Le Goïc, N., Lambert, C., de Montaudouin, X., Fabioux, C., Hégaret, H., 2014. Physiological responses of Manila clams Venerupis (=Ruditapes) philippinarum with varying parasite Perkinsus olseni burden to toxic algal Alexandrium ostenfeldii exposure. Aquat. Toxicol. 154, 27-38. https://doi.org/10.1016/j.aquatox.2014.05.002

Lassudrie, M., Wikfors, G.H., Sunila, I., Alix, J.H., Dixon, M.S., Combot, D., Soudant, P., Fabioux, C., Hégaret, H., 2015. Physiological and pathological changes in the eastern oyster Crassostrea virginica infested with the trematode Bucephalus sp. and exposed to the toxic dinoflagellate Alexandrium fundyense. J. Invertebr. Pathol. 126, 51-63. https://doi.org/10.1016/j.jip.2015.01.011

Lassus, P., Chomérat, N., Hess, P., Nézan, E., 2016. Toxic and harmful microalgae of the world ocean / Micro-algues toxiques et nuisibles de l'océan mondial, International Society for the Study of Harmful Algae / Intergovernmental Oceanographic Commission of UNESCO. ed, IOC Manuals and Guides. Denmark.

Latendresse, J.R., Warbrittion, A.R., Jonassen, H., Creasy, D.M., 2002. Fixation of testes and eyes using a modified Davidson's fluid: Comparison with Bouin's fluid and conventional Davidson's fluid. Toxicol. Pathol. 30, 524-533. https://doi.org/10.1080/01926230290105721

Le Goïc, N., Hégaret, H., Boulais, M., Béguel, J.-P., Lambert, C., Fabioux, C., Soudant, P., 2014. Flow cytometric assessment of morphology, viability, and production of reactive oxygen species of Crassostrea gigas oocytes: Application to toxic dinoflagellate (Alexandrium minutum) exposure. Cytom. Part J. Int. Soc. Anal. Cytol. 85, 1049-1056. https://doi.org/10.1002/cyto.a.22577

Le Goïc, N., Hégaret, H., Fabioux, C., Miner, P., Suquet, M., Lambert, C., Soudant, P., 2013. Impact of the toxic dinoflagellate Alexandrium catenella on Pacific oyster reproductive output: Application of flow cytometry assays on spermatozoa. Aquat. Living Resour. 26, 8. https://doi.org/10.1051/alr/2013047

Lelong, A., Haberkorn, H., Le Goïc, N., Hégaret, H., Soudant, P., 2011. A new insight into allelopathic effects of Alexandrium minutum on photosynthesis and respiration of the diatom Chaetoceros neogracile revealed by photosynthetic-performance analysis and flow cytometry. Microb. Ecol. 62, 919-930. https://doi.org/10.1007/s00248-011-98895

Llewellyn, L.E., 2006. Saxitoxin, a toxic marine natural product that targets a multitude of receptors. Nat. Prod. Rep. 23, 200-222. https://doi.org/10.1039/B501296C

Long, M., Tallec, K., Soudant, P., Lambert, C., Le Grand, F., Sarthou, G., Jolley, D., Hégaret, H., 2018. A rapid quantitative fluorescence-based bioassay to study allelochemical interactions from Alexandrium minutum. Environ. Pollut. https://doi.org/10.1016/j.envpol.2018.07.119

Ma, H., Krock, B., Tillmann, U., Muck, A., Wielsch, N., Svatoš, A., Cembella, A., 2011. Isolation of activity and partial characterization of large non-proteinaceous lytic allelochemicals produced by the marine dinoflagellate Alexandrium tamarense. Harmful Algae 11, 65-72. https://doi.org/10.1016/j.hal.2011.07.004

Mardones, J.I., Dorantes-Aranda, J.J., Nichols, P.D., Hallegraeff, G.M., 2015. Fish gill damage by the dinoflagellate Alexandrium catenella from Chilean fjords: Synergistic action of ROS and PUFA. Harmful Algae 49, 40-49. https://doi.org/10.1016/j.hal.2015.09.001

Mat, A.M., Haberkorn, H., Bourdineaud, J.-P., Massabuau, J.-C., Tran, D., 2013. Genetic and genotoxic impacts in the oyster Crassostrea gigas exposed to the harmful alga 
Alexandrium minutum. Aquat. Toxicol. 140-141, 458-465. https://doi.org/10.1016/j.aquatox.2013.07.008

Mat, A.M., Klopp, C., Payton, L., Jeziorski, C., Chalopin, M., Amzil, Z., Tran, D., Wikfors, G.H., Hégaret, H., Soudant, P., Huvet, A., Fabioux, C., 2018. Oyster transcriptome response to Alexandrium exposure is related to saxitoxin load and characterized by disrupted digestion, energy balance, and calcium and sodium signaling. Aquat. Toxicol. 199, 127-137. https://doi.org/10.1016/j.aquatox.2018.03.030

Matsuyama, Y., Usuki, H., Uchida, T., Kotani, Y., 2001. Effects of harmful algae on the early planktonic larvae of the oyster, Crassostrea gigas. G.M. Hallegraeff, S.I. Blackburn, C.J. Bolch, R.J. Lewis (Eds.), Proceedings of the Ninth International Conference on Harmful Algal Blooms, IOC of UNESCO, Paris (2001), pp. 411-414.

Mello, D.F., Silva, P.M. da, Barracco, M.A., Soudant, P., Hégaret, H., 2013. Effects of the dinoflagellate Alexandrium minutum and its toxin (saxitoxin) on the functional activity and gene expression of Crassostrea gigas hemocytes. Harmful Algae 26, 45-51. https://doi.org/10.1016/j.hal.2013.03.003

Mu, C., Li, Q., 2013. Effects of the dinoflagellate Alexandrium catenella on the early development of the Pacific oyster Crassostrea gigas. J. Shellfish Res. 32, 689-694. https://doi.org/10.2983/035.032.0310

Parker, L.M., Ross, P.M., O’Connor, W.A., Borysko, L., Raftos, D.A., Pörtner, H.-O., 2012. Adult exposure influences offspring response to ocean acidification in oysters. Glob. Change Biol. 18, 82-92. https://doi.org/10.1111/j.1365-2486.2011.02520.x

Payton, L., Perrigault, M., Hoede, C., Massabuau, J.-C., Sow, M., Huvet, A., Boullot, F., Fabioux, C., Hegaret, H., Tran, D., 2017. Remodeling of the cycling transcriptome of the oyster Crassostrea gigas by the harmful algae Alexandrium minutum. Sci. Rep. 7. https://doi.org/10.1038/s41598-017-03797-4

Petton, B., Boudry, P., Alunno-Bruscia, M., Pernet, F., 2015. Factors influencing diseaseinduced mortality of Pacific oysters Crassostrea gigas. Aquac. Environ. Interact. 6, 205-222. https://doi.org/10.3354/aei00125

Pousse, É., Flye-Sainte-Marie, J., Alunno-Bruscia, M., Hégaret, H., Rannou, É., Pecquerie, L., Marques, G.M., Thomas, Y., Castrec, J., Fabioux, C., Long, M., Lassudrie, M., Hermabessiere, L., Amzil, Z., Soudant, P., Jean, F., 2018. Modelling paralytic shellfish toxins (PST) accumulation in Crassostrea gigas by using Dynamic Energy Budgets (DEB). J. Sea Res. https://doi.org/10.1016/j.seares.2018.09.002

Pouvreau, S., Daniele, M., Auby, I., Lagarde, F., Le Gall, P., Cochet, H., 2016. Velyger database: the oyster larvae monitoring French project. SEANOE Doi 10, 41888.

Rolton, A., Vignier, J., Volety, A., Shumway, S., Bricelj, V.M., Soudant, P., 2018. Impacts of exposure to the toxic dinoflagellate Karenia brevis on reproduction of the northern quahog, Mercenaria mercenaria. Aquat. Toxicol. 202, 153-162. https://doi.org/10.1016/j.aquatox.2018.07.007

Rolton, A., Vignier, J., Volety, A.K., Pierce, R.H., Henry, M., Shumway, S.E., Bricelj, V.M., Hégaret, H., Soudant, P., 2016. Effects of field and laboratory exposure to the toxic dinoflagellate Karenia brevis on the reproduction of the eastern oyster, Crassostrea virginica, and subsequent development of offspring. Harmful Algae 57, 13-26. https://doi.org/10.1016/j.hal.2016.04.011

Rossini, G.P., 2014. Toxins and biologically active compounds from microalgae: Biological effects and risk management. Vol. 2. CRC Press.

Salvi, D., Mariottini, P., 2017. Molecular taxonomy in 2D: a novel ITS2 rRNA sequencestructure approach guides the description of the oysters' subfamily Saccostreinae and the genus Magallana (Bivalvia: Ostreidae). Zool. J. Linn. Soc. 179, 263-276. https://doi.org/10.1111/zoj.12455 
Steele, S., Mulcahy, M.F., 1999. Gametogenesis of the oyster Crassostrea gigas in southern Ireland. J. Mar. Biol. Assoc. U. K. 79, 673-686.

Suquet, M., Malo, F., Quéau, I., Ratiskol, D., Quéré, C., Le Grand, J., Fauvel, C., 2016. Seasonal variation of sperm quality in Pacific oyster (Crassostrea gigas). Aquaculture 464, 638-641. https://doi.org/10.1016/j.aquaculture.2016.07.016

Sussarellu, R., Suquet, M., Thomas, Y., Lambert, C., Fabioux, C., Pernet, M.E.J., Le Goïc, N., Quillien, V., Mingant, C., Epelboin, Y., Corporeau, C., Guyomarch, J., Robbens, J., Paul-Pont, I., Soudant, P., Huvet, A., 2016. Oyster reproduction is affected by exposure to polystyrene microplastics. Proc. Natl. Acad. Sci. 113, 2430-2435. https://doi.org/10.1073/pnas.1519019113

Tang, Y.Z., Gobler, C.J., 2012. Lethal effects of Northwest Atlantic Ocean isolates of the dinoflagellate, Scrippsiella trochoidea, on Eastern oyster (Crassostrea virginica) and Northern quahog (Mercenaria mercenaria) larvae. Mar. Biol. 159, 199-210. https://doi.org/10.1007/s00227-011-1800-x

Tran, D., Ciutat, A., Mat, A., Massabuau, J.-C., Hégaret, H., Lambert, C., Le Goïc, N., Soudant, P., 2015. The toxic dinoflagellate Alexandrium minutum disrupts daily rhythmic activities at gene transcription, physiological and behavioral levels in the oyster Crassostrea gigas. Aquat. Toxicol. 158, 41-49. https://doi.org/10.1016/j.aquatox.2014.10.023

Tran, D., Haberkorn, H., Soudant, P., Ciret, P., Massabuau, J.-C., 2010. Behavioral responses of Crassostrea gigas exposed to the harmful algae Alexandrium minutum. Aquaculture 298, 338-345. https://doi.org/10.1016/j.aquaculture.2009.10.030

Ubertini, M., Lagarde, F., Mortreux, S., Le Gall, P., Chiantella, C., Fiandrino, A., Bernard, I., Pouvreau, S., Roque d'Orbcastel, E., 2017. Gametogenesis, spawning behavior and larval abundance of the Pacific oyster Crassostrea gigas in the Thau lagoon: Evidence of an environment-dependent strategy. Aquaculture 473, 51-61. https://doi.org/10.1016/j.aquaculture.2017.01.025

Vasconcelos, V., Azevedo, J., Silva, M., Ramos, V., 2010. Effects of marine toxins on the reproduction and early stages development of aquatic organisms. Mar. Drugs 8, 5979. https://doi.org/10.3390/md8010059

Walne, P.R., 1970. Studies on the food value of nineteen genera of algae to juvenile bivalves of the genera Ostrea, Crassostrea, Mercenaria and Mytilus. Fish Invest Ser 2 26, 1 62.

Yan, T., Zhou, M., Fu, M., Wang, Y., Yu, R., Li, J., 2001. Inhibition of egg hatching success and larvae survival of the scallop, Chlamys farreri, associated with exposure to cells and cell fragments of the dinoflagellate Alexandrium tamarense. Toxicon 39, 12391244. https://doi.org/10.1016/S0041-0101(01)00080-0

Yan, T., Zhou, M., Fu, M., Yu, R., Wang, Y., Li, J., 2003. Effects of the dinoflagellate Alexandrium tamarense on early development of the scallop Argopecten irradians concentricus. Aquaculture 217, 167-178. https://doi.org/10.1016/S00448486(02)00117-5 